\title{
Intramedullary hemorrhage from a thoracic dural arteriovenous fistula
}

Xiaodong Niu, MD,* Hao Liu, MD,* and Jin Li, MD, PhD

Neurology ${ }^{\circledR}$ 2020;95:881-882. doi:10.1212/WNL.0000000000010881

Figure 1 Preoperative spinal MRI
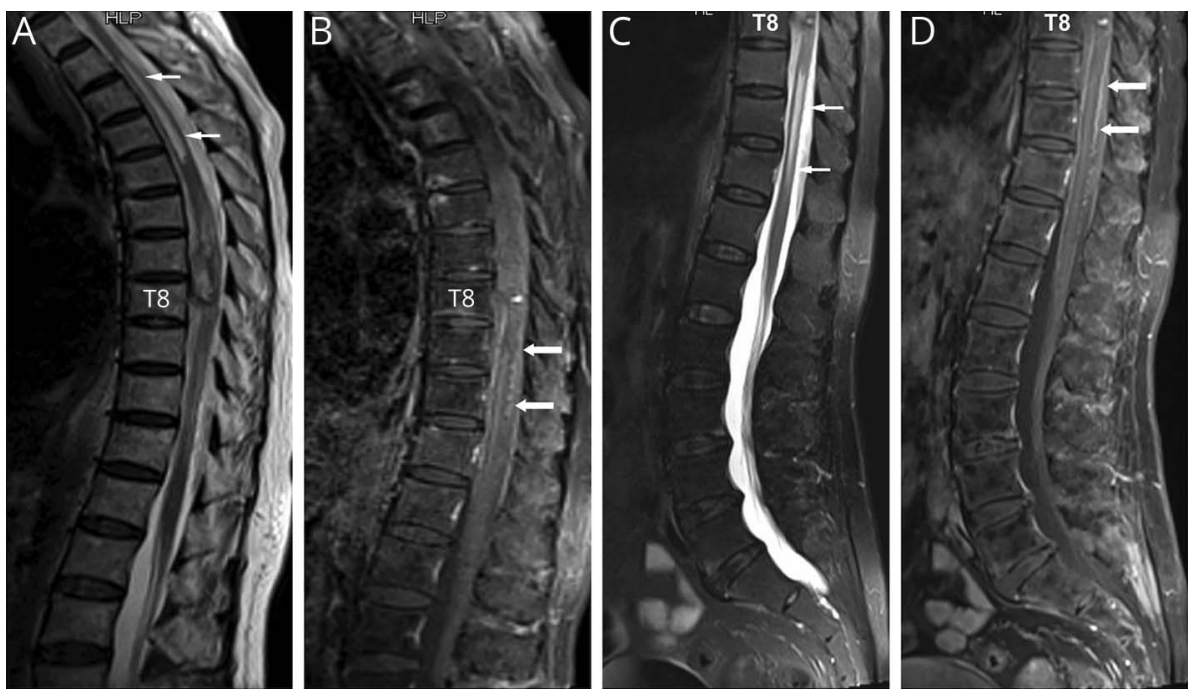

(A, B) Thoracic and (C, D) lumbar T2-weighted and contrast-enhanced MRI show T7-8 intramedullary hemorrhage, extensive spinal edema from T3 to T11 (thin arrows), and enhanced perimedullary veins (thick arrows).

A 64-year-old woman presented with sudden lower back pain and loss of power in both legs (grade 0/5). Spinal MRI demonstrated a focal abnormal area at T7-8 level, consistent with intramedullary hemorrhage (figure 1). Selective angiography revealed a right $\mathrm{T} 9$ spinal dural arteriovenous fistula (DAVF) and an associated venous varix (figure 2). The fistula was treated successfully with surgery. The strength of the lower limbs improved postoperatively (grade $2 / 5$ ). Intramedullary hemorrhage caused by spinal DAVF is extremely rare. ${ }^{1,2}$ The presence of venous varix may be the cause of hematomyelia. This case shows clearly the associated venous varix with $3 \mathrm{D}$ images.

\section{Acknowledgment}

The authors thank the patient for granting permission to publish this information.

\section{Study funding}

No targeted funding reported.

\section{Disclosure}

The authors report no disclosures relevant to the manuscript. Neurology.org/ $\mathrm{N}$ for full disclosures.

*X. Niu and H. Liu are co-first authors.

From the Department of Neurosurgery, West China Hospital of Sichuan University, Chengdu, China.

Go to Neurology.org/N for full disclosures. 

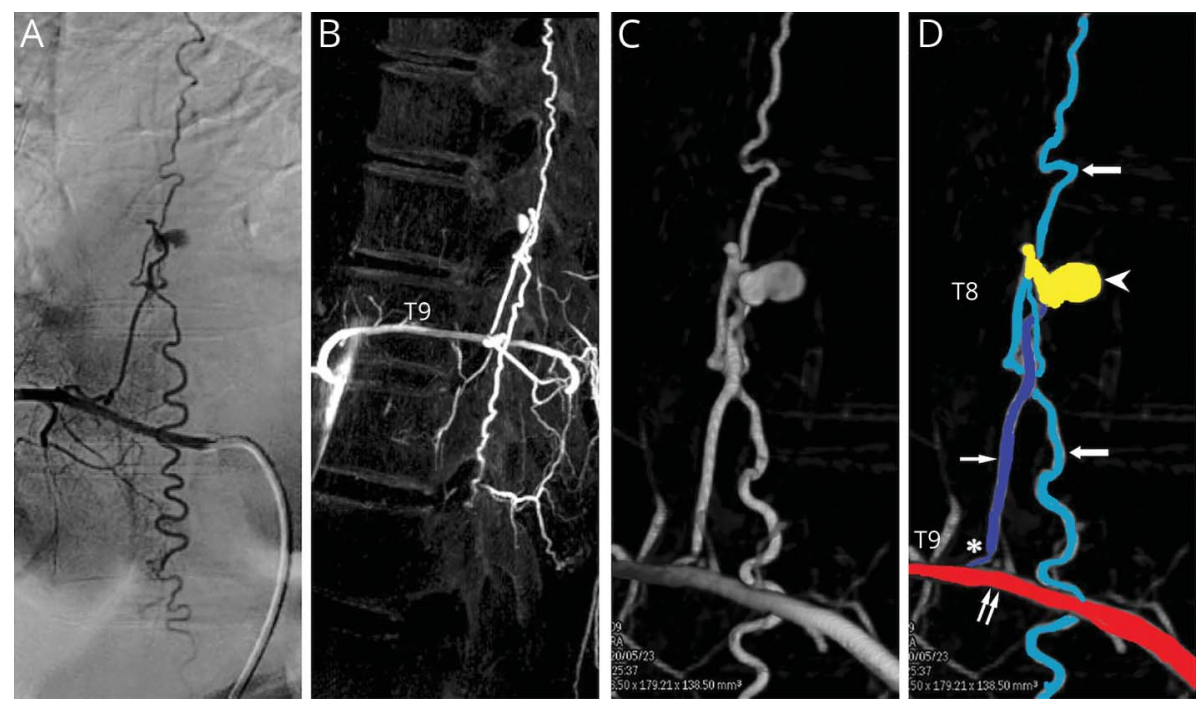

(A) Anteroposterior 2D and (B) lateral 3D angiography show a spinal dural arteriovenous fistula (asterisk) arising from the right T9 intercostal artery (double thin arrows) and an associated venous varix within the draining radiculomedullary vein (thick arrow). (C) Reconstructed 3D angiography and (D) corresponding schematic illustration demonstrate the associated venous varix (arrowhead) of the draining vein.

\begin{tabular}{lll}
\multicolumn{2}{l}{ Appendix } & Authors \\
\hline Name & Location & Contribution \\
\hline $\begin{array}{l}\text { Xiaodong } \\
\text { Niu, MD }\end{array}$ & $\begin{array}{l}\text { Sichuan } \\
\text { University, } \\
\text { Chengdu, } \\
\text { China }\end{array}$ & $\begin{array}{l}\text { Designed the study, collected and } \\
\text { analyzed the data, drafted the } \\
\text { manuscript }\end{array}$ \\
$\begin{array}{lll}\text { Hao Liu, } \\
\text { MD }\end{array}$ & $\begin{array}{l}\text { Sichuan } \\
\text { University, } \\
\text { Chengdu, } \\
\text { China }\end{array}$ & $\begin{array}{l}\text { Data collection and analysis, drafted } \\
\text { and revised }\end{array}$ \\
\hline
\end{tabular}

\begin{tabular}{lll} 
Appendix & (continued) & \\
\hline Name & Location & Contribution \\
\hline $\begin{array}{lll}\text { Jin Li, MD, } \\
\text { PhD }\end{array}$ & $\begin{array}{l}\text { Sichuan } \\
\text { University, } \\
\text { Chengdu, China }\end{array}$ & $\begin{array}{l}\text { Critically reviewed and revised the } \\
\text { manuscript }\end{array}$ \\
\hline
\end{tabular}

\section{References}

1. Hamdan A, Padmanabhan R. Intramedullary hemorrhage from a thoracolumbar dural arteriovenous fistula. Spine J 2015;15:e9-e16.

2. Minami M, Hanakita J, Takahashi T, et al. Spinal dural arteriovenous fistula with hematomyelia caused by intraparenchymal varix of draining vein. Spine J 2009;9:e15-e19.

\section{COVID-19 and Neurologic Disease: Call for Papers!}

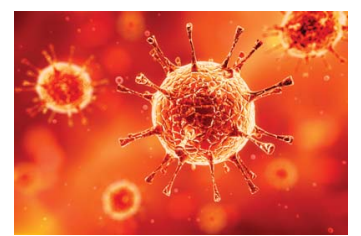

The editors of Neurology are interested in papers that address the neurological aspects of COVID-19 infection and challenges to the management of patients with chronic neurological conditions who have, or are at risk for, the infection. Relevant papers that pass initial internal review will undergo expedited peer review and online publication. We will consider papers posted in preprint servers.

Submit observational studies and clinical trials as Articles and case series and case reports under the Clinical/Scientific Notes category to https://submit.neurology.org/ today! 


\section{Neurology}

\section{Intramedullary hemorrhage from a thoracic dural arteriovenous fistula Xiaodong Niu, Hao Liu and Jin Li}

Neurology 2020;95;881-882 Published Online before print September 16, 2020

DOI 10.1212/WNL.0000000000010881

This information is current as of September 16, 2020

\section{Updated Information \&} Services

References

Subspecialty Collections

Permissions \& Licensing

Reprints including high resolution figures, can be found at: http://n.neurology.org/content/95/19/881.full

This article cites 2 articles, 0 of which you can access for free at: http://n.neurology.org/content/95/19/881.full\#ref-list-1

This article, along with others on similar topics, appears in the following collection(s):

\section{All Spinal Cord}

http://n.neurology.org/cgi/collection/all_spinal_cord Arteriovenous malformation

http://n.neurology.org/cgi/collection/arteriovenous_malformation

Information about reproducing this article in parts (figures,tables) or in its entirety can be found online at:

http://www.neurology.org/about/about_the_journal\#permissions

Information about ordering reprints can be found online:

http://n.neurology.org/subscribers/advertise

Neurology ${ }^{\circledR}$ is the official journal of the American Academy of Neurology. Published continuously since 1951, it is now a weekly with 48 issues per year. Copyright @ 2020 American Academy of Neurology. All rights reserved. Print ISSN: 0028-3878. Online ISSN: 1526-632X.

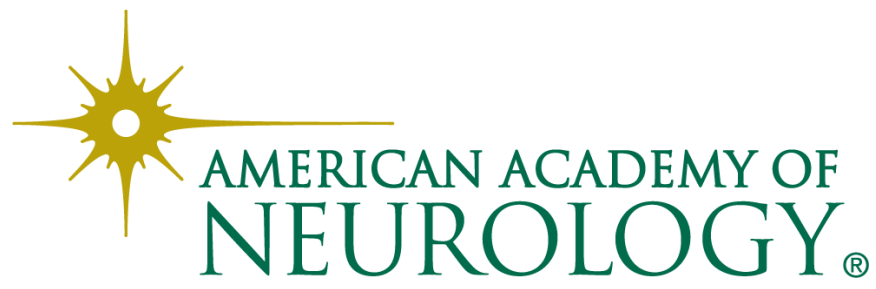

